\title{
Machine operator dies after head crushed in machine
}

\section{SUMMARY}

On March 30, 2006, a 38-year-old production machine operator was fatally injured while making adjustments to a flatbed thermoforming machine at a plastics manufacturing company. The machine operator and a coworker were making final adjustments on the oven and platen stop of the machine to run a different product. The machine operator rolled out the oven and began working inside the oven cavity while the coworker made adjustments to the top platen, about 4 feet away on the opposite side of the oven. After calling the warning "clear," the coworker lowered the platen by activating a pneumatic toggle, so he could make a final adjustment. Discovering a small

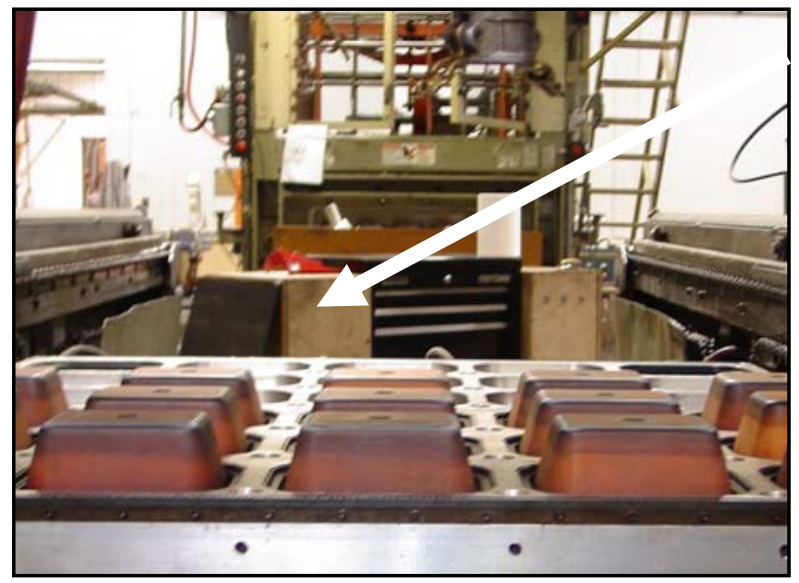

This interior view of the plastic thermoforming machine shows the oven cavity (arrow) where the machine operator was working to adjust the alignment of the molds and bottom platen (in foreground). part was missing, the coworker climbed off the machine and looked for the machine operator. He found him injured under the machine. The coworker called on his cell phone to the supervisor for help, and 911 was called. The victim was taken to a hospital and underwent several surgeries. He remained in a comatose state until his death 53 days following the incident.

\section{CAUSE OF DEATH: Traumatic head injury}

\section{RECOMMENDATIONS}

- Perform all appropriate lockout/tag out procedures to control hazardous energy before conducting maintenance inside machinery.

- Before starting a machine, make sure all safety mechanisms are in place, such as interlock devices and machine guards.

- Employers must train all workers assigned to operate or maintain machinery on appropriate energy-control procedures for that specific piece of equipment.

- Employers should conduct regular hazard inspections and follow through with necessary corrective actions. 


\section{INTRODUCTION}

On March 30, 2006, a 38-year-old production machine operator at a plastics manufacturing company was fatally injured while setting up a flatbed thermoforming machine. OR-FACE was notified of the worker's death by Oregon OSHA on June 27, 2006. The employer declined interviews with an OR-FACE investigator. This report is based on information from Oregon OSHA and medical examiner reports.

The employer was a large plastics thermoforming manufacturing plant, with two Oregon locations. In business since 1959, the nonunion firm produced rigid plastic packaging, and heavy-gauge forms and sheets for the electronics, food, industrial, medical, nursery, recreation and transportation industries. The plant where the incident occurred operated continuously, 24 hours a day, seven days a week. The plant employed about 188 of the firm’s 320 total workers. The incident occurred on the swing shift in the Packaging Department when 10 to 15 workers were present.

The human resources manager also functioned as the safety manager and the firm had a written safety program, a safety committee, and monthly safety training sessions. The firm had established written lockout/tag out procedures for specific machinery, including procedures for the flatbed thermoformer machine, but the manufacturer's operation and maintenance instructions were not all included in the lockout procedure. Training workers to operate, set up, and adjust the machine, for example, did not include how to control pneumatic energy to the oven-drive motor to protect any worker entering the machine's oven cavity area, or how to perform lockout when more than one worker sets up the machine.

The production machine operator had worked as a set-up and maintenance worker at the plastics plant before becoming a machine operator for the thermoform machine. He had operated the machine about 7 years. Setting up the machine with new molds could be accomplished by one person, either the machine operator or a set-up person, but they occasionally worked together as in this incident.

\section{INVESTIGATION}

Arriving for the swing shift, a machine operator and a shift set-up worker began to perform maintenance and make final adjustments to a pneumatic-controlled flatbed thermoforming machine after the molds had been changed in the machine during an earlier shift. The machine has top and bottom platens, actuated by a pneumatic toggle assembly. The machine's oven can be manually rolled out with a ratchet. The day staff had shut down the electrical energy to the machine, removed the guards and front safety cage, and inserted a new mold.

The swing-shift crew started to align the mold and adjust the height of the top platen, so when it opened, the newly-formed product would clear the mold. The machine operator rolled the oven out to a position where he could get into the oven cavity area, then began to make adjustments inside the cavity. The coworker was about 4 feet away, on the opposite side of the oven, making adjustments to the machine's top platen stop. 
After adjusting the platen stop, the setup worker yelled "clear" - the signal he regularly used to warn that he was going to activate the pneumatic toggle switch. Although electrical energy had been shut down, the switch remained energized by an independent air supply. The coworker looked through the oven area, and did not see the machine operator (or by a second account, did see the machine operator making final adjustments outside the oven). Other running machinery in the plant made a noisy environment, which made verbal communication between the two workers difficult.

The coworker activated the toggle switch on the pneumatic valve to lower the top

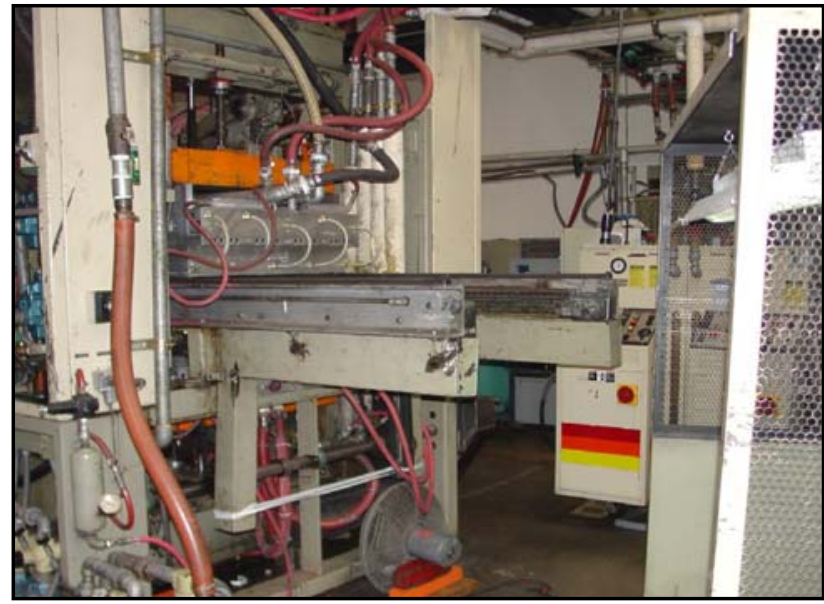

This front view of the plastic thermoformer machine shows where the set-up worker was making adjustments to the top platen, while the machine operator was working in the rear of the machine to adjust the oven. The pneumatic hose on the left of the machine remained energized during the adjustments. platen 4-8 inches, leaving an 8-inch clearance. The top platen would not completely lower, so he repeated the procedure, and then locked the toggle switch in the down position to make further adjustments to the platen stop before raising the platen again. He then left the machine to retrieve a wrench from his tool box in another area of the plant, intending to tighten a nut that secured the platen stop.

Returning to the thermoformer machine, the coworker looked into the mold to remove the front two line-up rings, but found only one ring. The machine operator generally removed the other two rings, so the coworker went to the rear of the machine to find him and confirm that he had the missing ring. He found the machine operator lying on his back on the floor under the machine where he had been working, bleeding from the face. Although several alternative mechanisms of injury were considered, the report of the medical examiner and conclusion of the OR-OSHA investigator indicate the operator was caught in the oven space when the platen was lowered, resulting in a crushing head injury. No one reported hearing or witnessing the event. (The three line-up rings were later found on the floor under the machine by coworkers.)

The coworker called on his cell phone to his supervisor, advising that the operator was hurt. He also asked a passing coworker to get help. First responders pulled the victim from under the machine, provided emergency aid, and transported him to the local emergency department. After several surgeries over 3 weeks, the victim was transferred to a care facility, where he persisted in a comatose state, and died 53 days following the incident. 


\section{RECOMMENDATIONS/DISCUSSION}

\section{Recommendation \#1. Perform all appropriate lockout/tag out procedures to control hazardous energy before conducting maintenance inside machinery.}

Individual lockout devices to shut down all energy sources, including pneumatic sources, must be applied prior to conducting maintenance or adjustment in the operating areas of a machine. In this incident, even though the machine was electrically de-energized at the time of the incident, pneumatic energy used to operate the platens and oven motor could not be locked out. No control mechanism was available. The manufacturer's instructions specified that the air infeed line should be shut down before making adjustments, but the procedure was not included in the firm's written lockout procedures. In addition, a block to place between the platens and prevent them from closing while working inside the oven area was available but not used.

When two persons are working on a machine for maintenance or adjustments, both workers should use an individual key to lockout all energy sources. Applied here, this procedure would have ensured that both workers were present and clear of machine hazards before the machine was started.

The coworker's later uncertainty whether he actually saw the machine operator outside the oven demonstrates the importance of a lockout procedure. A machine operator should stop and make sure all persons are clear of danger points before re-energizing or starting a machine, but verbal or visual confirmation cannot substitute for the physical lockout of the machine with separate keys by each worker involved.

\section{Recommendation \#2. Before starting a machine, make sure all safety mechanisms are in place, such as interlock devices and machine guards.}

Do not bypass safety interlock circuits or other safety devices. In this incident, the thermoform machine was equipped with four safety interlock devices on the access doors of each side of the machine. These devices prevent machine operation when the access doors or gates are opened. In this incident, all interlock devices were disconnected or bypassed.

\section{Recommendation \#3. Employers must train all workers assigned to operate or maintain machinery on appropriate energy-control procedures for that specific piece of equipment.}

Training on lockout/tag out procedures should include specific procedures for each machine. Written hazardous energy programs and training must include the manufacturer's operating instructions. A machine operator should be aware of and follow all of the manufacturer's instructions and safety recommendations.

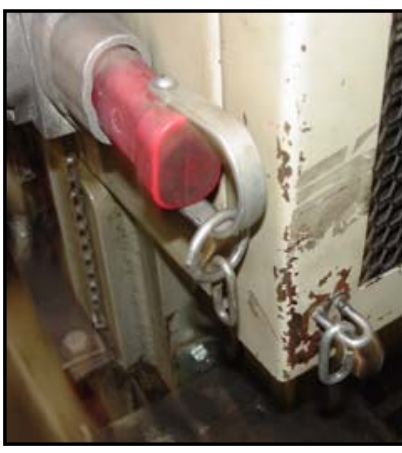

One of the disconnected safety interlocks on the thermoform machine would have prevented start-up if a gate was open. 
The manufacturer's operational manual included information on the use and placement of guards during operation and adjustment, including interlocked guards that shut down the machine when opened. The machine itself was equipped with various safety warning signs, including: "Do not alter electrical, pneumatic or hydraulic circuits without contacting [the manufacturer].”

Employers need to maintain written records related to hazardous-energy program training to assure adequate and accurate training over time. A written record is also useful for tracking compliance by supervisors and workers. Employee retraining should be conducted whenever there is reason to believe an employee has inadequate knowledge of or deviates from the use of safe work procedures.

\section{Recommendation \#4. Employers should conduct regular hazard inspections and follow through with necessary corrective actions.}

Hazard inspections should ensure all safety devices are in place and lockout/tag out procedures are being followed by machine operators and set-up workers. In the case here, periodic inspections of energy-control procedures could have identified and corrected the bypass of the machine's safety interlock system. Hazard inspections are best performed regularly. Corrective actions should be completed by a scheduled date.

\section{REFERENCES}

Center for Research on Occupational and Environmental Toxicology. CROETWeb.

Lockout/Tagout: www.croetweb.com/links.cfm?subtopicID $=250$

Machine guarding: www.croetweb.com/links.cfm?subtopicID=251

National Institute for Occupational Safety and Health. (1999). Preventing worker deaths from uncontrolled release of electrical, mechanical, and other types of hazardous energy. Available online: www.cdc.gov/niosh/99-110.html

Occupational Safety and Health Administration. (2005). Control of hazardous energy (lockout/tagout). Online resource: www.osha.gov/SLTC/controlhazardousenergy/index.html

Oregon OSHA. Machine safeguarding at the point of operation (2006). [Pub 440-2980]. Available online: www.cbs.state.or.us/external/osha/pdf/pubs/2980.pdf

Oregon OSHA. (2005). Hazardous energy: OR-OSHA's guide to controlling hazardous energy. Available online: www.orosha.org/pdf/pubs/3326.pdf

Oregon OSHA. 2005). Safety committees for the real world. Available online: www.cbs.state.or.us/external/osha/pdf/pubs/2341.pdf 


\section{FOR MORE INFORMATION}

Oregon Fatality Assessment and Control Evaluation (OR-FACE)

Center for Research on Occupational and Environmental Toxicology (CROET)

Oregon Health \& Science University (OHSU)

3181 SW Sam Jackson Park, L606

Portland OR 97239-3098

Phone 503-494-2281

Email: orface@ohsu.edu

Website: www.ohsu.edu/croet/face/

CROET at OHSU performs OR-FACE investigations through a cooperative agreement with the National Institute for Occupational Safety and Health (NIOSH), Division of Safety Research. The goal of these evaluations is to prevent fatal work injuries in the future by studying the work environment, the worker, the task, the tools, the fatal energy exchange, and the role of management in controlling how these factors interact.

Oregon FACE reports are for information, research, or occupational injury control only. Safety and health practices may have changed since the investigation was conducted and the report was completed. Persons needing regulatory compliance information should consult the appropriate regulatory agency. 